\title{
Cytogenetic studies in three species of Lutjanus (Perciformes: Lutjanidae: Lutjaninae) from the Isla Margarita, Venezuela
}

\author{
Mauro Nirchio ${ }^{1}$, Rodolfo Rondón ${ }^{1}$, Claudio Oliveira², Irani A. Ferreira ${ }^{2}$, Cesar Martins ${ }^{2}$, \\ Julio Pérez ${ }^{3}$, Luciana Sola ${ }^{4}$ and Anna Rita Rossi ${ }^{4}$
}

In the present study, three species of Lutjaninae, Lutjanus analis, L. griseus and L. synagris, were analyzed by conventional Giemsa staining, C-banding and silver staining, to reveal active Nucleolus Organizer Regions (NORs). Fluorescent in situ hybridization (FISH) was also applied to establish the number and location of the ribosomal gene clusters (18S and 5S rRNA genes). Counts of diploid metaphasic cells revealed a diploid modal chromosome complement composed of 48 acrocentric chromosomes in both $L$. analis and L. griseus. Two cytotypes were observed in L. synagris: cytotype I, with $2 \mathrm{n}=48$ acrocentric chromosomes, found in 19 specimens, and cytotype II, with 46 acrocentric chromosomes and one large metacentric, found in two specimens. The large metacentric, which possibly originated from a Robertsonian rearrangement, was not found to be sexrelated. In the three species, constitutive heterochromatin is located in the centromeres of all chromosomes. NORs were detected on the short arms of a single chromosome pair, number 24 in L. analis and number 6 in both cytotypes of L. synagris. In L. griseus, a polymorphism of the NORs number was detected, by both Ag-staining and FISH, as females show a maximum of three NORs, and males a maximum of six NORs. In all species, minor ribosomal genes were found located on a single chromosome pair. The obtained data, along with those previously reported for other five Lutjanidae species, show that a general chromosome homogeneity occurs within the family, but that derived karyotypes based on Robertsonian rearrangements as well as multiple and variable NORs sites can also be found.

No presente estudo três espécies de Lutjaninae, Lutjanus analis, L. griseus e L. synagris foram analisadas através da coloração convencional com Giemsa, banda C e coloração com nitrato de prata para identificar as Regiões Organizadoras de Nucléolo (NORs) ativas. Hibridação fluorescente in situ (FISH) foi também aplicada para estabelecimento do número e localização dos agrupamentos de genes ribossômicos (18S e $5 \mathrm{~S}$ rRNA). A contagem de células metafásicas revelou um número diplóide modal de 48 cromossomos acrocêntricos em L. analis e L. griseus. Dois citótipos foram observados em L. synagris: citótipo I com $2 n=48$ cromossomos acrocêntricos, encontrado em 19 espécimes, e citótipo II com 46 cromossomos acrocêntricos e um grande metacêntrico, encontrado em dois espécimes. O grande metacêntrico, que possivelmente se originou por um rearranjo Robertsoniano, não está relacionado com o sexo. Nas três espécies a heterocromatina constitutiva está localizada nas regiões centroméricas de todos os cromossomos. NORs foram detectadas no braço curto de um único par cromossômico, número 24 em L. analis e número $6 \mathrm{em}$ ambos os citótipos de L. synagris. Em L. griseus, um polimorfismo de número de NORs foi observado, após coloração com prata e por FISH, as fêmeas apresentaram um máximo de três NORs e os machos um máximo de seis NORs. Em todas as espécies os genes ribossômicos $5 \mathrm{~S}$ foram encontrados em um único par cromossômico. Os dados obtidos, somados aos demais previamente publicados para cinco outras espécies de Lutjanidae, mostram que na família há uma homogeneidade cromossômica, porém também são encontrados cariótipos derivados, originados por rearranjos Robertsonianos, assim como pela ocorrência de sítios múltiplos e variados de NORs.

Key words: Karyotype, Ribosomal genes, NOR polymorphism, C-banding, Robertsonian rearrangement.

\footnotetext{
${ }^{1}$ Escuela de Ciencias Aplicadas del Mar, Universidad de Oriente, Apartado Postal 147, Porlamar, Venezuela. mnirchio@cantv.net ${ }^{2}$ Departamento de Morfologia, Instituto de Biociências Universidade Estadual Paulista, 18618-000 Botucatu, São Paulo, Brazil. ${ }^{3}$ Instituto Oceanográfico de Venezuela, Universidad de Oriente, Cumaná, Venezuela.

${ }^{4}$ Department of Human and Animal Biology, University of Rome "La Sapienza", via Borelli 50, 00161 Rome, Italy.
} 


\section{Introduction}

The Lutjanidae (snappers) is a group composed of 17 genera and 105 species of mostly reef-associated marine fishes, which are distributed in all the tropical and subtropical seas of the world (Nelson, 2006). The family is divided in four subfamilies. Three smaller subfamilies include the Paradichthyinae, with two monotypic genera (Symphorus and Symphorichthys), the Etelinae, with five genera (Aphareus, Aprion, Etelis, Pristipomoides and Rhandallichthys) and 19 species, and the Apsilinae, with four genera (Apsilus, Lipocheilus, Paracesio and Parapristipomoides) and 12 species (Nelson, 2006). The subfamily Lutjaninae is the largest, with three monotypic genera (Hoplopagrus, Ocyurus and Rhomboplites), the genera Macolor and Pinjalo with two species each, and the genus Lutjanus, which is the most speciose, with 64 species. In Venezuela, Cervigón (1993) recognizes six genera of Lutjanidae (Etelis, Pristipomoides, Apsilus, Ocyurus, Rhomboplites and Lutjanus ) including 15 species, 10 of which belong to the genus Lutjanus (L. analis, L. apodus, L. aya, L. bucanella, L. cyanopterus, L. griseus, $L$. jocu, L. mahogoni, L. purpureus, L. synagris and L. vivanus).

In spite of their high number and their ecological and economic importance, cytogenetic studies on Lutjanidae are scarce. In fact, among the 105 recognized species of Lutjanidae, barely five species have been karyotyped to date: Lutjanus argentimaculatus (Raghunath \& Prasad, 1980), L. kasmira (Choudhury et al., 1979; Ueno \& Takai, 2008), L. sanguineus (Rishi, 1973), L. russelli (Ueno \& Ojima 1992), and L. quinquelineatus (Ueno \& Takai, 2008). For most of them, only the chromosome number and morphology have been reported and there is no data regarding the chromosomal distribution and composition of the constitutive heterochromatin or numbers and locations of the major and minor ribosomal genes, which have proved to be useful markers in the investigation of the phylogenetic relationships among fish species within a family (Sola et al., 2007).

In the present study, three species of Lutjaninae, Lutjanus analis, L. griseus and L. synagris were analyzed by conventional Giemsa staining and C-banding, and by Fluorescent in situ hybridization with $18 \mathrm{~S}$ rDNA and 5S rDNA, in order to obtain a fine karyotype characterization, and, thus, chromosome markers which can provide useful information concerning relationships within the family.

\section{Materials and Methods}

Eight sexually immature (unsexed) specimens of L. analis, seven specimens of L. griseus (3 males, 3 females, 1 unsexed) and 21 specimens of L. synagris (9 males, 10 females, 2 unsexed) were captured with a fishing trap in the locality of Guayacancito, on Margarita Island, Venezuela. Voucher specimens (Table 1) were deposited at the Ichthyology Collection of the Escuela de Ciencias Aplicadas del Mar (ECAM), Universidad de Oriente.

Twenty four hours before chromosome preparations, the fishes were injected intramuscularly with a yeast glucose solution (Lee \& Elder, 1980) for mitosis stimulation. Chromosomes were obtained from kidney cells according to Foresti et al. (1993). C-bands were obtained according to the method described by Sumner (1972), modified by testing different time of exposition to barium hydroxide, from 1 to $180 \mathrm{sec}-$ onds, in order to enhance the contrast of constitutive heterochromatin on chromosomes. For detection of the active Nucleolus Organizer Regions (NORs), slides were stained with silver nitrate using the method of Howell \& Black (1980).

The $5 \mathrm{~S}$ and $18 \mathrm{~S}$ rDNA sites were identified by FISH according to the method of Pinkel et al. (1986). A sequence of 1800 base pairs of the 18S rRNA gene of Oreochromis niloticus (Nile tilapia), cloned in pGEM-T plasmid, was used as a probe to localize sites for $45 \mathrm{~S}$ rDNA. PCR products containing 5S rDNA repeats from each species were used as probes for the chromosome mapping of 5S rDNA. DNA was extracted from muscle (Sambrook \& Russel, 2001) and the 5S rDNA repeats were generated by Polymerase Chain Reaction (PCR) with the primers 5SA (5'TAC GCC CGA TCT CGT CCG ATC3') and 5SB (5'CAG GCT GGT ATG GCC GTAAGC3') according to Martins \& Galetti (1999).

The 18S rDNA and 5S rDNA probes were labeled by nick translation with biotin-14-dATP, following the manufacturer's (Bionick $^{\mathrm{TM}}$ Labelling System-Gibco.BRL) instructions. Signals were detected and amplified by a three-round application of Avidin-FITC/biotinilated Anti-avidin. Chromosomes were counter-stained with Propidium Iodide $(50 \mu \mathrm{g} / \mathrm{ml})$ diluted in Antifade.

The mitotic figures were photographed using a Motic B400 microscope equipped with a Moticam 5000C digital camera. The fundamental number (NF) of arms was determined considering acrocentrics (A) as having one chromosome arm and metacentrics (M) as having two chromosome arms. FISH metaphases were photographed with a Olympus BX61 photomicroscope equipped with a DP70 digital camera.

\section{Results}

The counts of diploid metaphasic cells (Table 1) revealed a modal chromosome complement composed of $2 \mathrm{n}=48$ acrocentric chromosomes $(\mathrm{NF}=48)$ in both $L$. analis and L. griseus and in 19 out of the 21 examined specimens of L. synagris (cytotype I). The two remaining specimens, one male and one unsexed, of L. synagris show a modal count of $2 \mathrm{n}=47(\mathrm{NF}=48)$, made up of one large metacentric and 46 acrocentric chromosomes. This karyomorph was named cytotype II. The karyotypes obtained by arranging the chromosomes in order of decreasing size are shown in Fig. 1. The negligible differences in chromosome sizes make it impossible to identify homologous pairs with any certainty, with the exception of a chromosome pair, classified as number 6, in L. analis (Fig. 1a), which shows a secondary constriction when chromosomes are elongated, and chromosome pair number 24 in all the three species, clearly the smallest of the chromosome complements. 


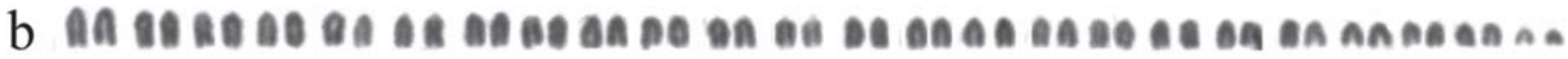

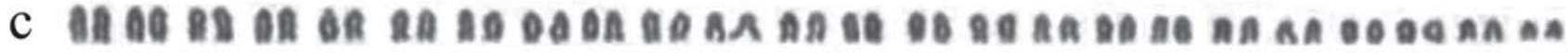

\section{$\mathrm{d}$}

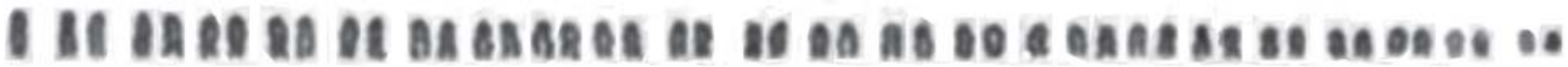

Fig. 1. Giemsa-stained karyotypes of Lutjanus analis (a), L. griseus (b), L. synagris cytotype I (c) and L. synagris cytotype II (d).

In all the three Lutjanus species examined, C-banding (Fig. 2) revealed that the heterochromatin is restricted to the centromeres of all chromosomes, including the large metacentric in cytotype II of L. synagris, though some of them show weaker signals.

The analysis of the nucleolus organizer regions with the Ag-NOR staining technique detected a maximum of two Agpositive paracentromeric signals in L. analis (Fig. 3 b) and in both cytotypes of L. synagris (Fig. 3d for cytotype I, data not shown for cytotype II). In L. analis the Ag-signals (Fig. 3b) are located on the secondary constriction, often evident in Giemsa-stained metaphases (Fig. 3a), of chromosome pair number 6. In L. synagris the Ag-signals (Fig. 3d) are located on the smallest chromosome pair number 24 of the complement. In L. griseus, a variable number of paracentromeric Agpositive signals per metaphase was observed, up to two in females (Fig. 4a, b) and up to four in males (Fig. 4c, d). By its morphology and size and for the presence of a secondary constriction (Fig. 4a, b), one of the NOR-bearing chromosome pair in this is likely to be homoeologous to the chromo-
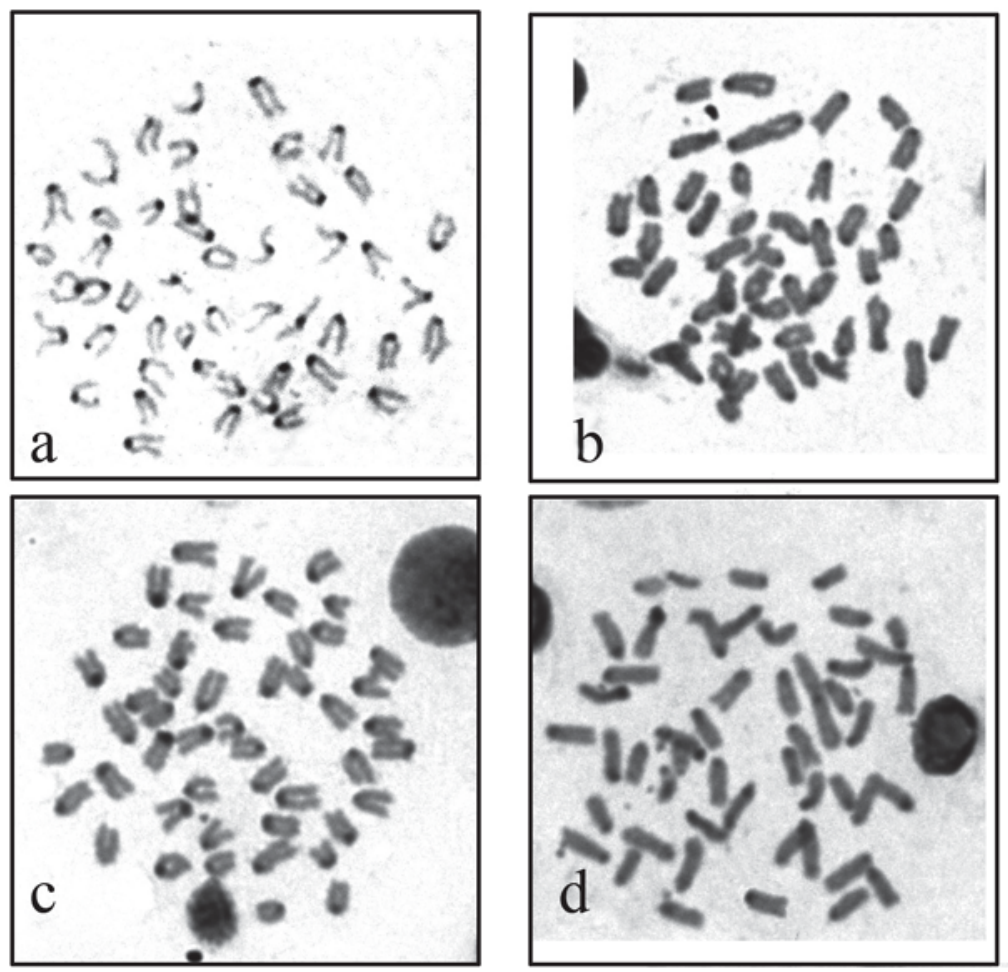

Fig. 2. C-banded metaphases of Lutjanus analis (a), L. griseus (b), L. synagris cytotype I (c) and L. synagris cytotype II (d). 


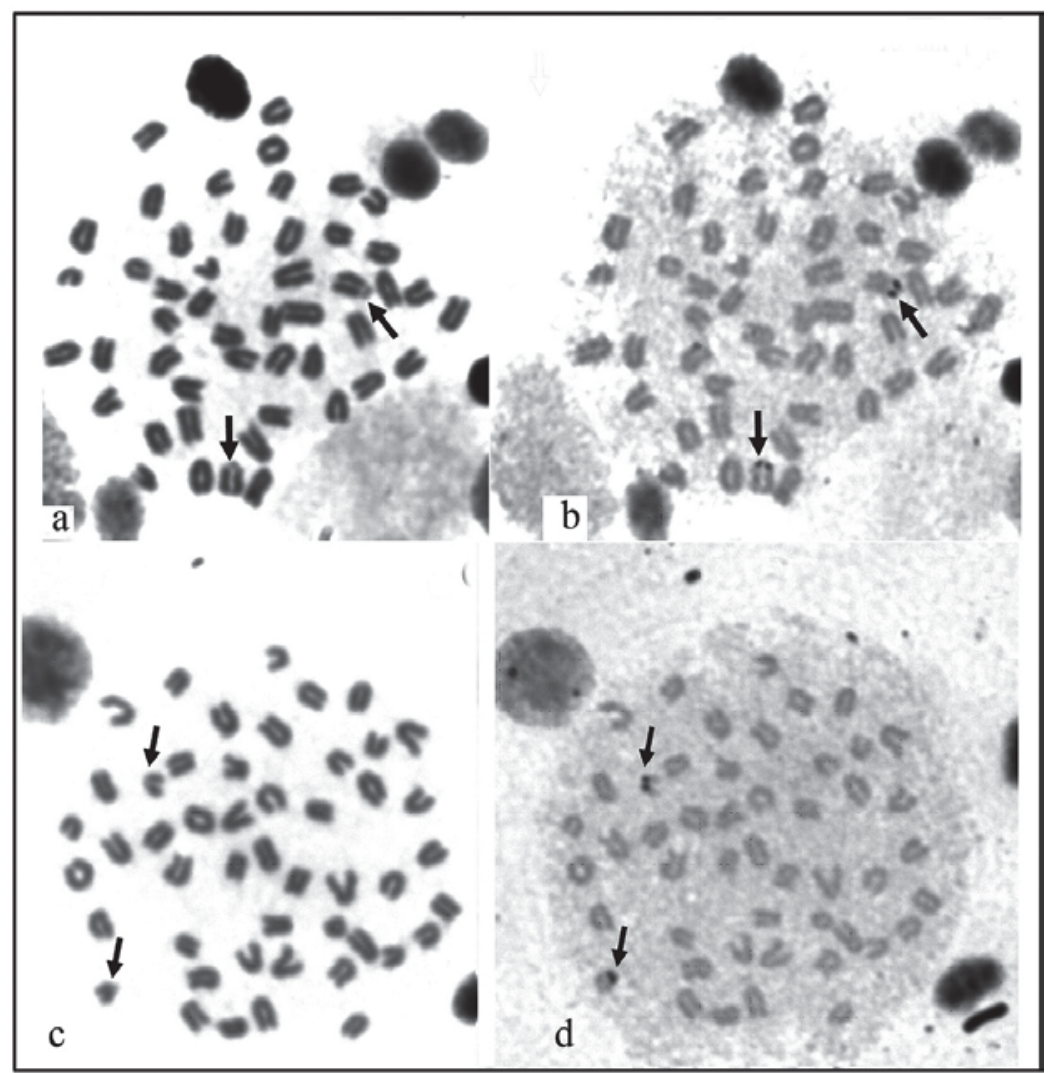

Fig. 3. Metaphases of Lutjanus analis (a; b), L. synagris cytotype I (c; d) sequentially stained with Giemsa (left) and AgNO (right). Arrows indicate the NOR bearing chromosomes.

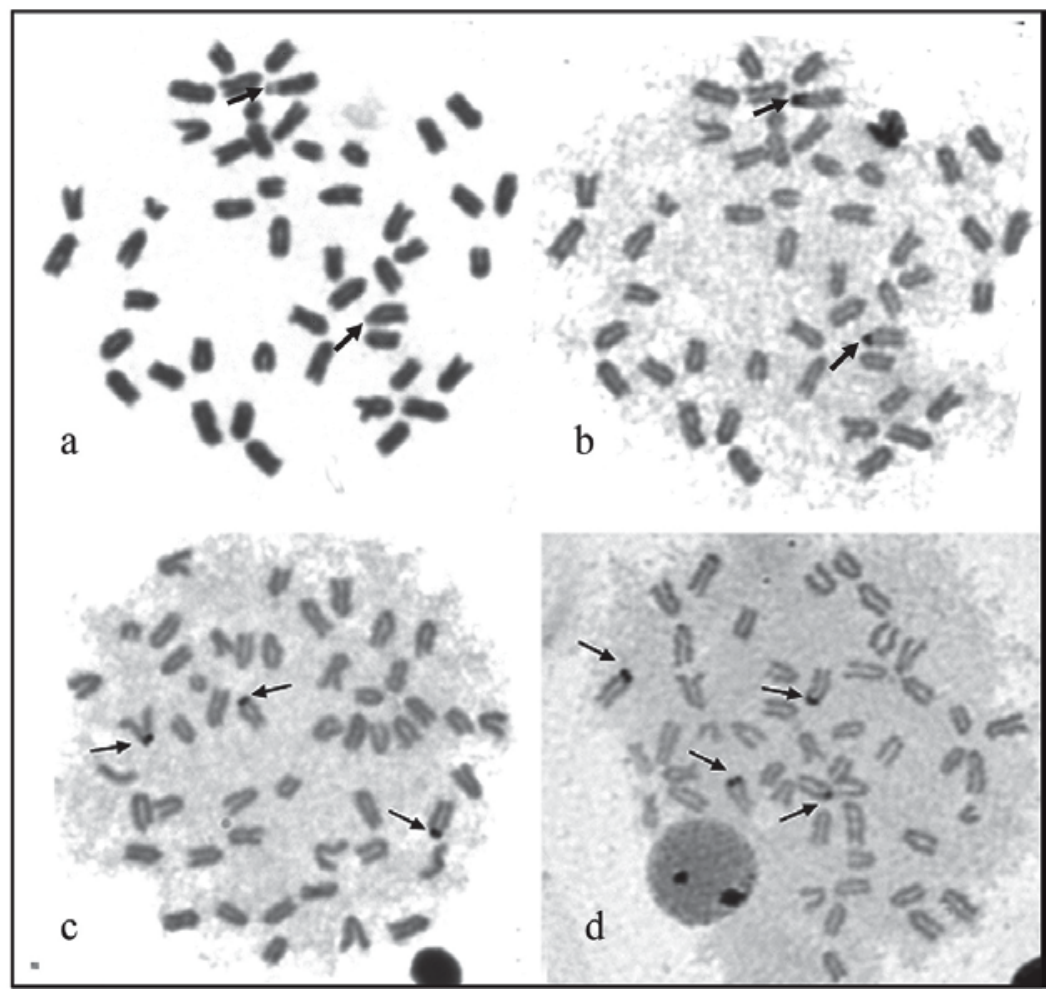

Fig. 4. Metaphases of Lutjanus griseus, with two (b), three (c) or four (d) Ag-NORs (arrows). In (a) the same metaphase as (b) previously stained with Giemsa. 
some pair number 6 identified in L. analis (Fig. 3a, b). The remaining signals are located on medium-sized chromosomes.

After FISH with 18S rDNA, in L. analis and in L. synagris two fluorescence hybridization signals were seen at the same chromosome locations detected with Ag-staining, i.e., in paracentromeric positions of chromosome pair number 6 in $L$. analis (Fig. 5a) and of chromosome pair number 24 in both cytotypes of L. synagris (Fig. 5c, e), confirming that in these species a single pair of NOR-bearing chromosomes is present. In L. griseus (Fig. 6) hybridization with $18 \mathrm{~S}$ rDNA confirms the NORs sites detected by Ag-staining, but also reveals further positive sites, so that up to three NORs were observed in females (Fig. 6a) and up to six in males (Fig. 6b). All FISH positive chromosomes are medium-sized, thus major ribosomal gene clusters location on chromosome pair 24 can be excluded.

After FISH with 5S rDNA, in all species - L. analis (Fig. 5b), both cytotypes of L. synagris (Fig. 5d, f) and L. griseus (Fig. 6c) - one cluster of 5S rRNA genes was found close to the centromere of a medium-sized acrocentric chromosome pair, which is apparently the same in the three species.

\section{Discussion}

The cytogenetic features here reported for the examined specimens of L. analis, L. griseus and L. synagris revealed that the three species have the 48-acrocentric karyotype which is shared by most of the Lutjaninae species previously analyzed, such as Lutjanus argentimaculatus (Raghunath \& Prasad, 1980), L. kasmira (Choudhury et al., 1979; Ueno \& Takai, 2008), L. sanguineus (Rishi, 1973) and L. russelli (Ueno \& Ojima, 1992). The only exception is L. quinquelineatus which has been reported to possess $2 \mathrm{n}=48 \mathrm{~A}$ in females and $2 \mathrm{n}=47(1 \mathrm{M}+46 \mathrm{~A})$ in males (Ueno \& Takai, 2008).

In fish, Robertsonian rearrangements, which, by fusions (or fissions) of two uniarmed chromosomes into one biarmed chromosome (or vice-versa), cause changes in chromosome number, but leave the fundamental number of arms unchanged, are infrequent. However, examples of Robertsonian polymorphism in marine fishes have been reported for species of Gobiidae (Gobius paganellus, Giles et al., 1985; Neogobius eurycephalus, Ene, 2003), Sparidae (Diplodus annularis, Vitturi et al., 1996), Pomacentridae (Chromis insolata and $C$. flavicauda, Molina \& Galetti, 2002), Cottidae (Myoxocephalus scorpius, Yershov, 2005), Gadidae and Pleuronectidae ( $G a-$ dus morhua and Pleuronectes platessa, Fana \& Fox, 1991). In this context, the presence of cytotype II, with a large unpaired metacentric chromosome, found in one male and one unsexed specimen of L. synagris, is quite interesting. In fact, when chromosome differences are restricted to one sex, the presence of sex chromosomes is strongly suggested (Devlin $\&$ Nagahama, 2002). As a matter of fact, the presence of $2 n=48$ acrocentric chromosomes in females and $2 n=47(1 \mathrm{M}+46 \mathrm{~A})$ in males of L. quinquelineatus was interpreted by Ueno \& Takai (2008) as the result of a single Robertsonian fusion which formed a neo-Y chromosome, establishing a multiple sex chro- mosome system of $\mathrm{X}_{1} \mathrm{X}_{1} \mathrm{X}_{2} \mathrm{X}_{2} / \mathrm{X}_{1} \mathrm{X}_{2} \mathrm{Y}$ type. In the case reported here for $L$. synagris, the reduced $2 \mathrm{n}=47$ cytotype II characterizes only two (one male, one immature) of the 21 specimens analyzed, but, among these latter, the remaining eight males present the same 48 acrocentric chromosome cytotype I shown by all ten females and one immature specimens. Thus, the two cytotypes co-exist in different males and the presence of the large unpaired metacentric chromosome does not seem to be associated to sex determination. Due to the frequency of cytotype II, approximately $9.5 \%$, this rearrangement suggests the existence of a chromosomal polymorphism in the studied population of L. synagris. Nevertheless, the possibility that the observed fusion in L. synagris might originate a neo-Y chromosome and that an incipient stage of multiple sex chromosome differentiation, as the one reported in L. quinquelineatus (Ueno \& Takai, 2008), has been identified, can not be discarded.

In all the three Lutjanus species examined, the C-positive heterochromatin distribution is restricted to the centromeres

Table 1. Number of scored cell and percentages of different diploid counts in specimens of the three species of Lutjanus examined. Undetermined sex (?), male (M), and female (F).

\begin{tabular}{|c|c|c|c|c|c|c|c|}
\hline \multirow{2}{*}{$\begin{array}{c}\text { Species } \\
\text { (n) }\end{array}$} & \multirow{2}{*}{$\begin{array}{l}\text { Voucher } \\
\text { number }\end{array}$} & \multirow{2}{*}{ Sex } & \multirow{2}{*}{$\begin{array}{l}\text { Number of } \\
\text { scored cells }\end{array}$} & \multicolumn{4}{|c|}{ Frequency } \\
\hline & & & & 46 & 47 & 48 & 49 \\
\hline \multirow{9}{*}{$\begin{array}{l}\text { L. analis } \\
\text { (8) }\end{array}$} & ECAM-365 & $?$ & 45 & 8.9 & 11.1 & 73.3 & 6.7 \\
\hline & ECAM-366 & $?$ & 26 & 3.8 & 11.5 & 76.9 & 7.7 \\
\hline & ECAM-422 & $?$ & 24 & 0.0 & 8.3 & 87.5 & 4.2 \\
\hline & ECAM-425 & $?$ & 34 & 0.0 & 5.9 & 85.3 & 8.8 \\
\hline & ECAM-426 & $?$ & 28 & 7.1 & 3.6 & 85.7 & 3.6 \\
\hline & ECAM-427 & $?$ & 40 & 2.5 & 7.5 & 85.0 & 5.0 \\
\hline & ECAM-405 & $?$ & 38 & 0.0 & 7.9 & 81.6 & 10.5 \\
\hline & ECAM-428 & $?$ & 15 & 0.0 & 13.3 & 80.0 & 6.7 \\
\hline & \multicolumn{2}{|l|}{ Subtotal } & 250 & 2.8 & 8.6 & 81.9 & 6.7 \\
\hline \multirow{8}{*}{$\begin{array}{l}\text { L. griseus } \\
\text { (7) }\end{array}$} & ECAM-399 & $\mathrm{F}$ & 67 & 4.5 & 7.5 & 82.1 & 6.0 \\
\hline & ECAM-408 & $?$ & 23 & 4.3 & 8.7 & 82.6 & 4.3 \\
\hline & ECAM-410 & M & 11 & 0.0 & 18.2 & 81.8 & 0.0 \\
\hline & ECAM-409 & $\mathrm{F}$ & 30 & 0.0 & 13.3 & 76.7 & 10.0 \\
\hline & ECAM-002 & $\mathrm{F}$ & 36 & 5.6 & 11.1 & 80.6 & 2.8 \\
\hline & ECAM-413 & M & 26 & 3.8 & 15.4 & 80.8 & 0.0 \\
\hline & ECAM-429 & M & 76 & 3.9 & 10.5 & 78.9 & 6.6 \\
\hline & \multicolumn{2}{|c|}{ Subtotal } & 269 & 3.2 & 12.1 & 80.5 & 4.2 \\
\hline \multirow{23}{*}{$\begin{array}{c}L . \\
\text { synagris } \\
(21)\end{array}$} & ECAM-364 & $?$ & 70 & 4.3 & 4.3 & 85.7 & 5.7 \\
\hline & ECAM-367 & $?$ & 56 & 5.4 & 83.9 & 7.1 & 3.6 \\
\hline & ECAM-423 & M & 16 & 6.3 & 12.5 & 75.0 & 6.3 \\
\hline & ECAM-424 & $\mathrm{F}$ & 59 & 3.4 & 10.2 & 81.4 & 5.1 \\
\hline & ECAM-430 & $\mathrm{F}$ & 49 & 6.1 & 10.2 & 77.6 & 6.1 \\
\hline & ECAM-438 & $\mathrm{F}$ & 83 & 3.6 & 4.8 & 83.1 & 8.4 \\
\hline & ECAM-439 & $\mathrm{F}$ & 26 & 0.0 & 3.8 & 88.5 & 7.7 \\
\hline & ECAM-451 & M & 47 & 8.5 & 76.6 & 10.6 & 4.3 \\
\hline & ECAM-452 & $\mathrm{F}$ & 64 & 3.1 & 6.3 & 84.4 & 6.3 \\
\hline & ECAM-453 & $\mathrm{F}$ & 33 & 3.0 & 9.1 & 84.8 & 3.0 \\
\hline & ECAM-454 & $\mathrm{F}$ & 25 & 16.0 & 8.0 & 72.0 & 4.0 \\
\hline & ECAM-455 & M & 50 & 6.0 & 14.0 & 74.0 & 6.0 \\
\hline & ECAM-456 & $\mathrm{F}$ & 38 & 5.3 & 7.9 & 81.6 & 5.3 \\
\hline & ECAM-457 & $\mathrm{F}$ & 51 & 5.9 & 7.8 & 78.4 & 7.8 \\
\hline & ECAM-458 & M & 18 & 5.6 & 5.6 & 77.8 & 11.1 \\
\hline & ECAM-459 & M & 21 & 0.0 & 9.5 & 85.7 & 4.8 \\
\hline & ECAM-460 & M & 13 & 0.0 & 7.7 & 92.3 & 0.0 \\
\hline & ECAM-461 & M & 40 & 0.0 & 10.0 & 87.5 & 2.5 \\
\hline & ECAM-462 & $\mathrm{F}$ & 37 & 5.4 & 8.1 & 86.5 & 0.0 \\
\hline & ECAM-463 & M & 43 & 4.7 & 4.7 & 83.7 & 7.0 \\
\hline & ECAM-464 & $\mathrm{M}$ & 62 & 1.6 & 8.1 & 87.1 & 3.2 \\
\hline & \multicolumn{2}{|c|}{ Subtotal } & 901 & 4.5 & 14.9 & 75.5 & 5.1 \\
\hline & \multicolumn{2}{|l|}{ TOTAL } & 1440 & 3.5 & 11.9 & 79.2 & 5.45 \\
\hline
\end{tabular}




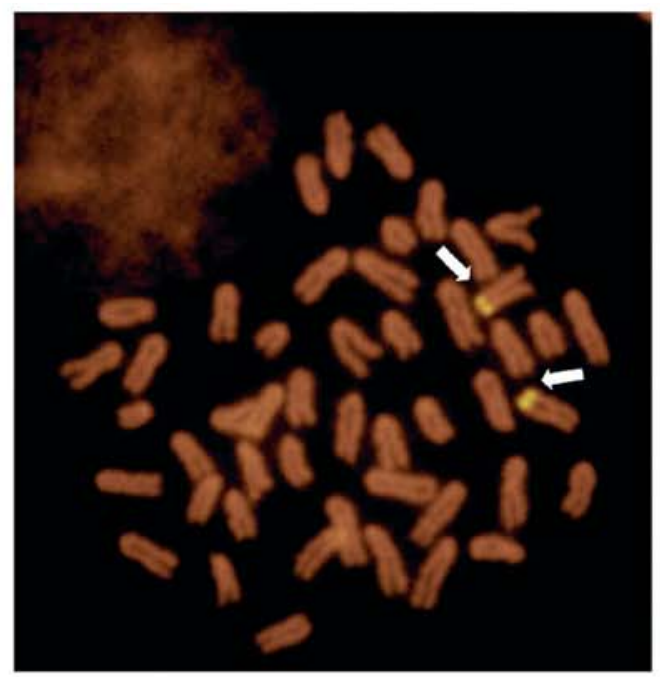

a

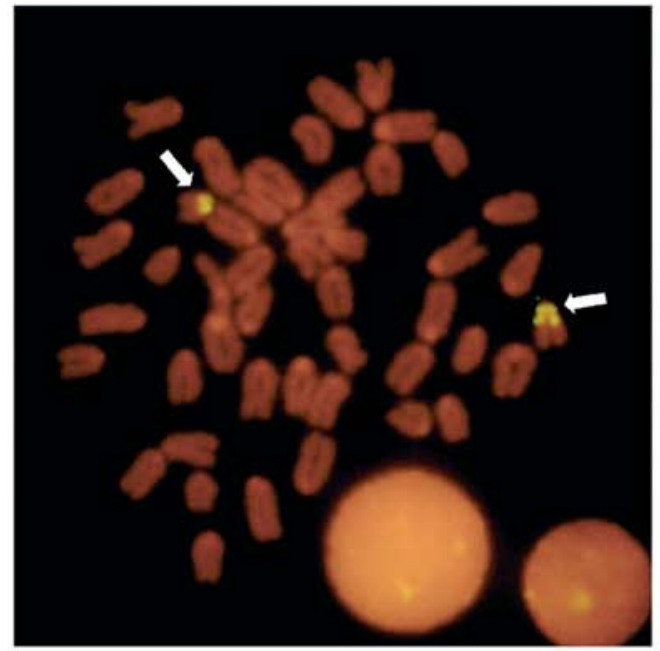

C

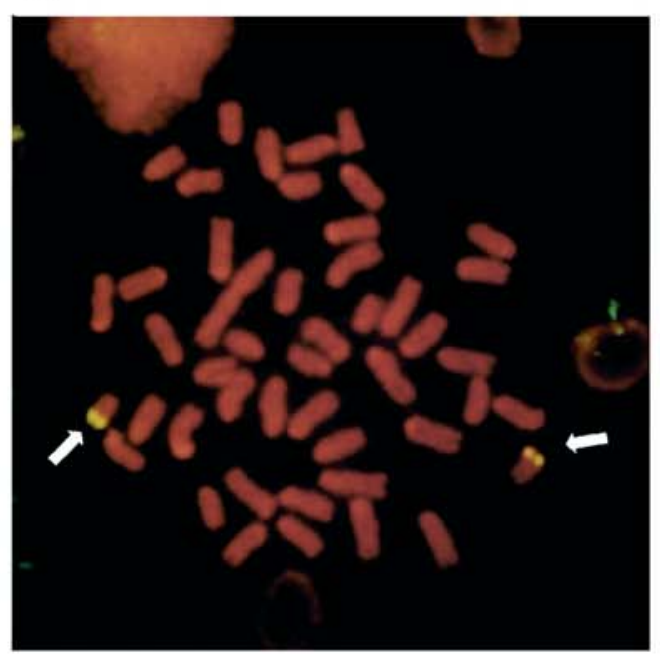

e

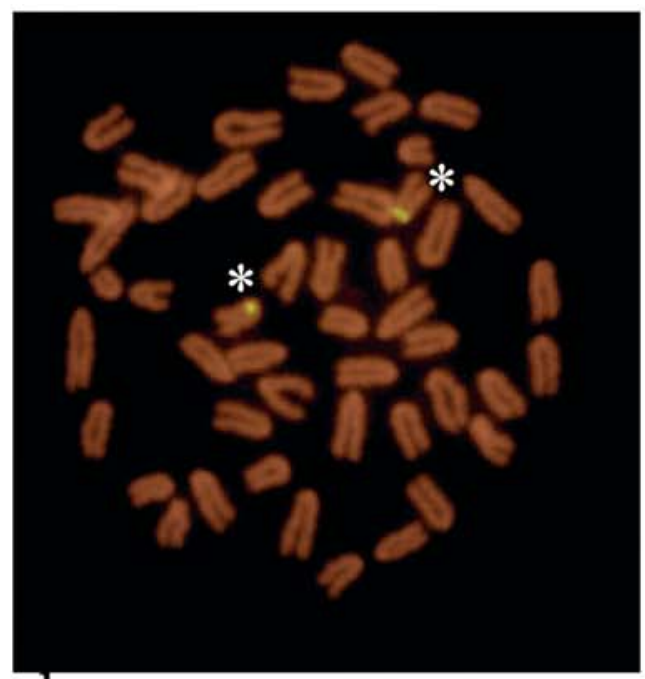

b

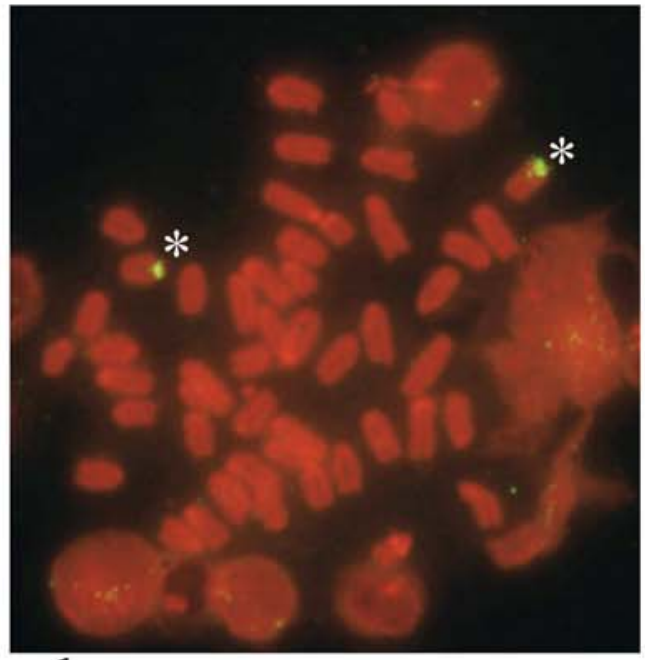

d

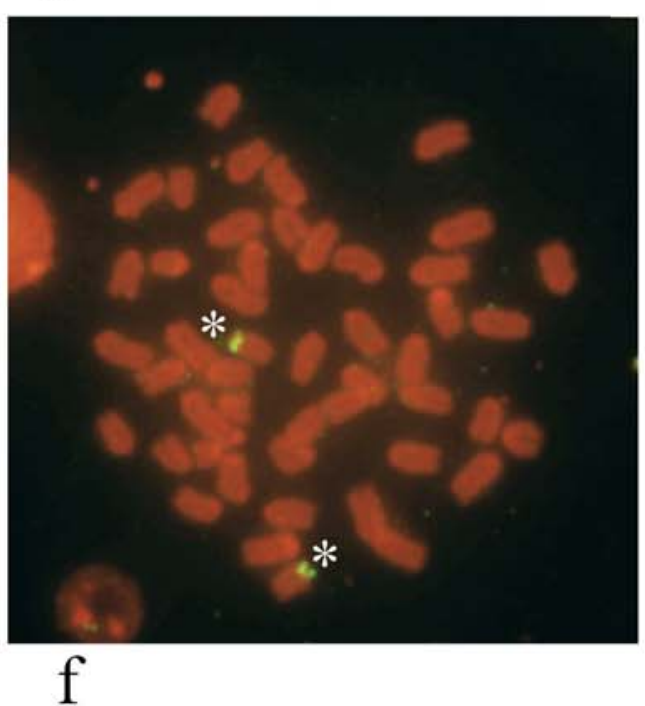

Fig. 5. Metaphases of Lutjanus analis (a, b), L. synagris cytotype I (c, d) and L. synagris cytotype II (e, f) after FISH with $18 \mathrm{~S}$ rDNA (left) and with 5S rDNA (right). Arrows indicate the NOR bearing chromosomes. Asterisks indicate the $5 \mathrm{~S}$ rDNA bearing chromosomes. 


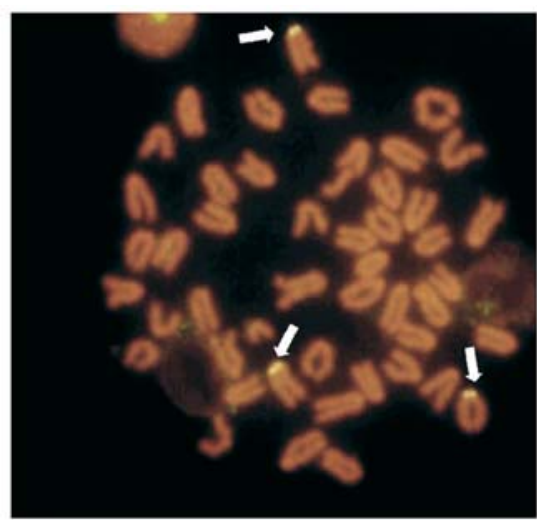

a

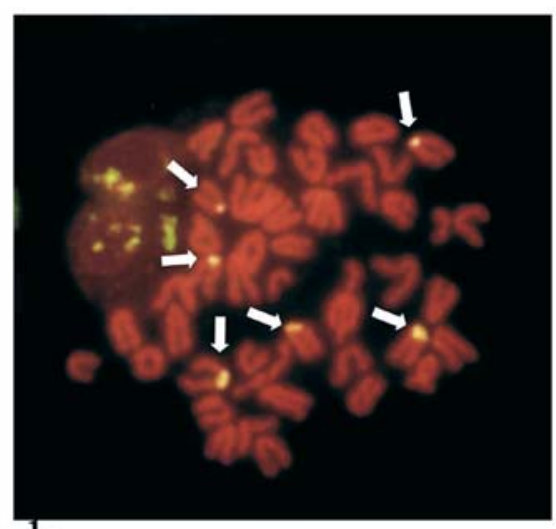

b

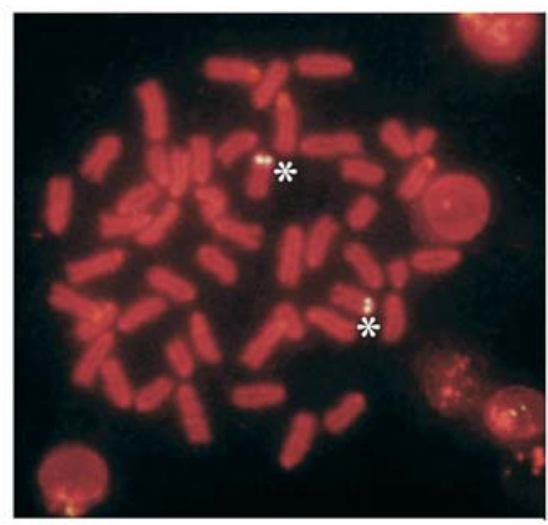

C

Fig. 6. Metaphases of Lutjanus griseus after FISH with 18S rDNA (arrows) in a female (a) and in a male (b) and (c) with 5S rDNA (asterisks).

of all chromosomes, a pattern similar to the one reported for the Pacific L. kasmira and L. quinquelineatus (Ueno \& Takai, 2008), the only two, among the five karyologically investigated Lutjaninae species, for which data are available. Although the heterochromatin distribution does not identify species-specific chromosome markers, it is worth noting that considerably different exposition times to $\mathrm{BaOH}$, during the C-banding procedure, were applied, from 4 seconds in $L$. analis, to 30 seconds in L. synagris and up to 180 seconds in L. griseus, a fact which might reflect differences in chromatin condensation levels and/or composition among the species of Lutjaninae here studied.

As far as NORs are concerned, different aspects can be considered. The first one is related to the methodology. In fish, NORs are usually indirectly visualized by silver staining (Nirchio \& Oliveira, 2006), which localizes the transcribing major ribosomal genes because silver precipitates in correspondence to a rRNA protein complex synthesized only when NORs are active in the preceding interphase (Hubbel 1985, Sánchez-Pina et al. 1984, Jimenez et al. 1988). However, recent evidence in some fish species (Gromicho et al., 2005) have cast doubt on the accuracy and reliability of Ag in NORs detection, both because other regions, besides NORs, can be stained with Ag or because most of the $28 \mathrm{~S}$ rDNA sites, as revealed by FISH, were not detected. In the studied species of Lutjaninae, all the Agpositive sites were also FISH-positive, so the technique is NORspecific, but FISH revealed the presence of additional and inactive NORs in only one of them, L. griseus, confirming that this species has a higher NOR variability, both in their number and location, compared to the other congeneric species. As far as this variability is concerned, though a sex-associated trend is identifiable, as males show a higher number of structural NORs, compared to females, a larger sample is needed to verify the extent and the basis of this variability.

A further aspect is related to the cytotaxonomic considerations. A single pair of NOR-bearing chromosomes has been suggested to represent the primitive karyotypical condition in most vertebrate species (Hsu et al., 1975; Schmidt, 1978). In most of the teleost fish displaying the primitive karyotype with 48 acrocentric chromosomes, two terminal NORs near the cen- tromere can be found (Vitturi et al., 1995). Therefore, on one hand, a single NOR bearing chromosome pair, with ribosomal sites interstitially located, as observed in L. analis and $L$. synagris (present study) and in L. kasmira and $L$. quinquelineatus (Ueno \& Takai, 2008), could be considered a plesiomorphic condition for Lutjanus, whereas the presence of multiple NOR bearing chromosomes, found in L. griseus, would be an apomorphic feature. These data would indicate that $L$. analis and L. synagris are more closely related, and that the occurrence of duplication and translocation of ribosomal genes in L. griseus might reflect an important mechanism involved in the diversification of this taxon. On the other, when considering NORs location, a different perspective highlights. Indeed, the single NOR-bearing chromosome pair observed in L. analis (chromosome pair 6), as well as one of the NOR-bearing chromosome pairs observed in L. griseus, when pursuing a parsimonious criterion, appears to be homeologous to the one identified both in L. kasmira and L. quinquelineatus (Ueno \& Takai, 2008), and, thus, it could be regarded as the primitive condition in the genus. As a consequence, no homeology could be identified with the NOR-bearing chromosome pair of L. synagris. Similar ambiguous results were obtained from molecular and morphological data. Indeed, in a phylogenetic study of Lutjanidae, based on isozyme and morphological data, Chow \& Walsh (1992) suggested that L. analis and L. synagris form a clade, which is a sister group of L. griseus. However, subsequent molecular phylogenetic studies, based on mitochondrial DNA (Sarver et al., 1996) have not provided a similar clear-cut subdivision.

FISH experiment with 5S rDNA, revealed their location on a chromosome which is clearly distinct from the one (number 24) bearing major rDNA genes in L. synagris, but, though the difference in size is smaller, also from the NOR bearing chromosome pair number 6 of L. analis and L. griseus. The 5S rRNA gene sites are usually located in separate areas from 45S rRNA genes of the genome in higher eukaryotes (Martins \& Galetti, 1999). This is probably because a separate location may permit them to independently evolve, since the divergent functional dynamics of these sequences require physical distancing (Martins \& Galetti, 2000). 
In conclusion, data here obtained for Lutjanus analis, $L$. griseus and L. synagris, along with those previously reported for L. kasmira and L. quinquelineatus (Ueno \& Takai, 2008), show that a general chromosome homogeneity occurs within the family, but that derived karyotypes based on Robertsonian rearrangements as well as multiple and variable NORs sites can also be found. Phylogenetic relationships among species remained unresolved and further data on the other species of Lutjanus are needed to obtain a more general picture of the karyoevolutive trends in the family.

\section{Acknowledgements}

Financial support was provided by Consejo de Investigación, Universidad de Oriente, Venezuela, by the Italian Ministry of Instruction, University and Research (MIUR), and by Fundação de Amparo a Pesquisa do Estado de São Paulo (FAPESP) Brazil and Conselho Nacional de Desenvolvimento Científico e Tecnológico (CNPq) Brazil.

\section{Literature Cited}

Cervigón, F. 1993. Los Peces Marinos de Venezuela. Volumen II. Fundación Científica Los Roques. Caracas - Venezuela. 499 p.

Choudhury, R. C., R. Prasad \& C. C. Das. 1979. Chromosomes of six species of marine fishes. Caryologia, 32: 15-21.

Chow, S. \& P. J. Walsh. 1992. Biochemical and morphometric analyses for phylogenetic relationships between seven snapper species (Subfamily: Lutjaninae) of the western Atlantic. Bulletin of Marine Science, 50: 508-519.

Devlin, R. H. \& Y. Nagahama. 2002. Sex determination and sex differentiation in fish: an overview of genetic, physiological, and environmental influences. Aquaculture, 208: 191-364.

Ene, A. C. 2003. Chromosomal polymorphism in the goby Neogobius eurycephalus (Perciformes: Gobiidae). Marine Biology, 142: 583-588.

Fana, Z. \& D. P. Fox. 1991. Robertsonian polymorphism in plaice, Pleuronectes platessa L., and cod, Gadus morhua L., (Pisces Pleuronectiformes and Gadiformes). Journal of Fish Biology, 38: 635-640.

Foresti F, C. Oliveira \& L. F. Almeida-Toledo. 1993. A method for chromosome preparations from large specimens of fishes using in vitro short treatment with colchicine. Experientia, 49: 810-813.

Giles, V., G. Thode \& C. Alvarez. 1985. A new Robertsonian fusion in the multiple chromosome polymorphism of a mediterranean population of Gobius paganellus (Gobiidae, Perciformes). Heredity, 55: 255-260.

Gromicho, M., C. Ozouf-Costaz \& M. J. Collares-Pereira. 2005. Lack of correspondence between $\mathrm{CMA}_{3}-$, Ag-positive signals and 28S rDNA loci in two Iberian minnows (Teleostei, Cyprinidae) evidenced by sequential banding. Cytogenetic and Genome Research, 109: 507-511.

Howell, W. M. \& D. A. Black. 1980. Controlled silver staining of nucleolus organizer regions with a protective colloidal developer: a 1-step method. Experientia, 3: 1014-1015.

Hubbel, H. R. 1985. Silver staining as an indicator of active ribosomal genes. Stain Technology, 60: 285-294.

Hsu, T. C., S, Patak \& T. R. Chen. 1975. The possibility of latent centromeres and a proposed nomenclature system for total chromosome and whole arm translocations. Cytogenetics and Cell Genetics, 15: 41-49.

Jiménez, R., M. Burgos \& R. Diaz de La Guardia. 1988. A study of the silver staining significance in mitotic NORs. Heredity, 60: 125-127.

Lee, M. R. \& F. F. B. Elder. 1980. Yeast stimulation of bone marrow mitosis for cytogenetic investigations. Cytogenetics and Cell Genetics, 26: 36-40.

Martins, C. \& P. M. Galetti Jr. 1999. Chromosomal localization of 5S rDNA genes in Leporinus fish (Anostomidae, Characiformes). Chromosome Research, 7: 363-367.

Martins, C. \& P.M. Galetti Jr. 2000. Conservative distribution of $5 \mathrm{~S}$ rDNA loci in Schizodon (Pisces, Anostomidae) chromosomes. Chromosome Research, 8: 353-355.

Molina, W. F. \& P. M. Galetti Jr. 2002. Robertsonian rearrangements in the reef fish Chromis (Perciformes, Pomacentridae) involving chromosomes bearing 5S rRNA genes. Genetics and Molecular Biology, 25: 373-377.

Nelson, J. S. 2006. Fishes of the World. 4th eds. New York: John Wiley and Sons, Inc. $601 \mathrm{p}$.

Nirchio, M. \& C. Oliveira. 2006. Citogenética de Peces/Editado por Universidad de Oriente, Cumaná, Venezuela, 216 p.

Pinkel D., T. Straume \& J. W. Gray. 1986. Cytogenetic analysis using quantitative, high-sensitivity, fluorescence hybridization. Proceedings of the National Academy of Sciences, 83: 2934-2938.

Raghunath, P. \& R. Prasad. 1980. Chromosomes of six marine percoids from the Indian Sea. Indian Biologist, 11: 9-12.

Rishi, K. K. 1973. A preliminary report on the karyotypes of eighteen marine fishes. Research Bulletin of the Panjab University, 24:161-162

Sambrook, J. \& D. W. Russell. 2001. Molecular cloning: a laboratory manual. Cold Spring Harbor Laboratory Press. Cold Spring Harbor, New York. 2344 pp

Sánchez-Pina, M. A., F. J. Medina, M. M. Fernández-Gómez \& M. C. Risueno. 1984. Ag-NOR proteins are present when transcription is impaired. Biology of the Cell, 5: 199-202.

Schmidt, M. 1978. Chromosome banding in Amphibia. II. Constitutive heterochromatin and nucleolus organizer regions in Ranidae, Microhylidae and Racophoridae. Chromosoma, 68: 131-148.

Sola, L., E. Gornung, M. E. Mannarelli \& A. R Rossi. 2007. Chromosomal evolution in Mugilidae, Mugilomorpha: an overview, Pp. 165-194. In: Pisano, E., C. Ozouf-Costaz, F. Foresti \& B. G. Kapoor (Eds.). Fish Cytogenetics. Science Publishers, Enfield, NH, USA. 502 p.

Sumner, A. T. 1972. A simple technique for demonstrating centromeric heterocromatin. Experimental Cell Research, 75: 304-306.

Ueno, K. \& Y. Ojima. 1992. Notes on the chromosomes of Girella melanichthys and Lutjanus russelli (Pisces, Perciformes). Chromosome Information Service, 52: 3-5.

Ueno, K \& A. Takai. 2008. Multiple sex chromosome system of $\mathrm{X}_{1} \mathrm{X}_{1} \mathrm{X}_{2} \mathrm{X}_{2} / \mathrm{X}_{1} \mathrm{X}_{2} \mathrm{Y}$ type in lutjanid fish, Lutjanus quinquelineatus (Perciformes). Genetica, 132: 35-41.

Vitturi, R., A. Libertini, A. Mazzola, M. S. Colomba \& G. Sara. 1996. Characterization of mitotic chromosomes of four species of the genus Diplodus: karyotypes and chromosomal nucleolar organizer region phenotypes. Journal of Fish Biology, 49: 1128-1137.

Yershov, P. N. 2005. Chromosomal studies of Zoarces viviparus L. (Zoarcidae) and Myoxocephalus scorpius L. (Cottidae) from different parts of distribution area. Ecohydrology and Hydrobiology, 5: 237-243.

Accepted December 2007 Published 31 March 2008 